\title{
Variation of sediment provenance at the 09 - 1 Block, Cuu Long Basin: their significance in assessing the Oligocene - Miocene reservoir quality
}

\author{
Anh Lam Nguyen ${ }^{1}$, Tung Thanh Nguyen ${ }^{2}$, Long Van Hoang ${ }^{2,}{ }^{*}$, Dung Viet Bui ${ }^{2}$, Hieu \\ Trung Nguyen ${ }^{2}$, Anh Tuan Nguyen ${ }^{2}$, Phuong Ngoc Thi Bui ${ }^{3}$, Trieu Tan Nguyen ${ }^{3}$, \\ Trung Thanh Trinh 4 \\ ${ }^{1}$ Russia-Vietnam Joint Venture (Vietsovpetro), Ba Ria - Vung Tau, Vietnam \\ ${ }^{2}$ Vietnam Petroleum Institute, Hanoi, Vietnam \\ ${ }^{3}$ Vietnam Petroleum Institute, Ho Chi Minh City, Vietnam \\ 4 Vietnam Administration of Seas and Islands, Hanoi, Vietnam
}

ARTICLE INFO

Article history:

Received 04 $4^{\text {th }}$ June 2021

Revised 31 ${ }^{\text {st }}$ Aug. 2021

Accepted 29th Sept. 2021

Keywords:

Cuu Long Basin,

Reservoir,

Sediment provenance.
ABSTRACT

The Cuu Long Basin is one of the Tertiary sedimentary basins situated on the continental shelf of Vietnam, which demonstrates the high potential of oil and gas. Apart from fractured granite reservoirs, the Oligocene Miocene sand bodies are thought to have significant potential for forming non - structural traps. The results of the study on the composition and physical properties of the sediments derived from wells " $X$ " and " $Y$ ", block 09 - 1, Cuu Long Basin show that there is a clear difference between the Late Oligocene and Early Miocene sandstone in the well " $X$ ", namely the Miocene sandstone shows larger particle size, higher roundness and sortness (TB: 434.2; Ro: 0.69; So: 2.22) than those of the Late Oligocene sandstone (TB: 104.28; Ro: 0.64; So: 1.46). This difference is likely attributed to the fact that the Miocene sandstone was influenced by the marine environment, which intensified the roundness and sortness. Meanwhile, the well " $Y$ " did not show much difference in the physical parameters of the sediments between the Late Oligocene and Early Miocene age ranges. However, the grain size was slightly increased and the roundness was less during the Early Miocene. It is possible that the " $Y$ " well is located closer to the local source. The variation in the physical parameters of the sediments, proportion of sand grains and clay minerals shows that the quality of late Oligocene reservoir is better than that of Early Miocene reservoir, and the Late Oligocene reservoir quality in the " $X$ " well is better than that in the borehole " $Y$ ".

${ }^{*}$ Corresponding author

E-mail: longhv@vpi.pvn.vn

DOI: 10.46326/JMES.2021.62 (5).03 


\title{
Biến đổi nguồn và đặc tính trầm tích tại lô 09 - 1 bồn trũng Cửu Long: Ý nghĩa của chúng trong đánh giá chất lượng đá chứa tuổi Oligocen - Miocen
}

\author{
Nguyễn Lâm Anh ${ }^{1}$, Nguyễn Thanh Tùng ${ }^{2}$, Hoàng Văn Long ${ }^{2,}$, Bùi Việt Dũng ${ }^{2}$, \\ Nguyễn Trung Hiếu 2, Nguyễn Tuấn Anh ${ }^{2}$, Bui Thi Ngoc Phương ${ }^{3}$, Nguyen Tan \\ Trieu ${ }^{3}$, Trinh Thanh Trung 4 \\ ${ }^{1}$ Liên doanh Việt - Nga (Vietsovpetro), Bà Rịa - Vũng Tàu, Việt Nam \\ 2 Viện Dầu khí Việt Nam, Hà Nội, Việt Nam \\ 3 Viện Dầu khí Việt Nam, TP. Hồ Chí Minh, Việt Nam \\ ${ }^{4}$ Tổng cục Biển và Hải đảo Việt Nam, Hà Nội, Việt Nam
}

THÔNG TIN BÀI BÁO T TÓM TẮT

Quá trình:

Nhận bài 04/6/2021

Sứa xong 31/8/2021

Chap nhận đăng 29/9/2021

Tù khóa:

Bể Cửu Long,

Nguồn trầm tích,

Via chứa.
Bể Cưu Long là một trong số các bể trầm tích Đê Tam trên thềm lục địa Việt Nam có nhiều tiềm năng dầu khí. Bên cạnh đối tượng đá chứa là đá móng granit nút nẻ thì các thân cát tuổi Oligocen-Miocen được cho là có nhiều triển vọng đểhình thành các bẫy phi cấu tạo. Kết quả nghiên cúu thành phần độ hạt trầm tích tại các giếng khoan " $X$ " và " $Y$ ", lô 09 - 1 bể Củu long cho thấy, có sự khác nhau rõ rệt trong cát kết tuổi Oligocen muộn và Miocen sớm ở giếng khoan " $X$ ", cu thể là cát kết Miocen có kích thước hạt trung bình, độ mài tròn, độ chọn lọc (TB: 434,2; Ro: 0,69; So: 2,22) cao hon so với cát kết Oligocen muộn (TB: 104,28; Ro: 0,64; So: 1,46). Sư khác biệt này được cho là tập cát kết Miocen bị ảnh hướng của môi trường biển làm gia tăng khả năng mài tròn, chọ lọc của trầm tích. Trong khi đó, giếng khoan "Y" không cho thấy nhiều sự khác biệt về các tham số vật lý trầm tích giữa hai khoảng tuổi Oligocen muộn và Miocen sóm. Tuy nhiên, kích thước hạt có tăng lên chút ít và độ mài tròn kém hon trong trầm tích Miocen sớm. Có thể giếng khoan " $Y$ " được đặt ở vi trí gần nguồn đia phưong hơn. Sự khác nhau về thông số độ hạt, tỉ lệ thành phần mảnh vụn và khoáng vật sét cho thấy chất lượng đá chứa Oligocen muộn tốt hơn so với đá chứa Miocen sớm và giếng khoan "X" có chất lượng đá chứa tốt hon so với giếng khoan " $Y$ ".

(C) 2021 Trường Đại học Mỏ - Địa chất. Tất cả các quyền được bảo đảm.
*Tác giả liên hệ

E-mail: longhv@vpi.pvn.vn

DOI: $10.46326 / J M E S .2021 .62$ (5).03

\section{Mở đầu}

Bể trầm tích Cửu Long là một trong những bể trầm tích Đệ Tam chứa dầu quan trọng nhất nằm về phía Đông Nam thềm lục địa Việt Nam với diện tích 
khoảng $36.000 \mathrm{~km}^{2}$. Bể được hình thành do quá trình phá hủy đá móng trước Kainozoi theo cơ chế rift nội lục, bắt đầu từ Eocen cho đến nay (Hoàng Ngọc Đông, 2012; Lê Văn Cự và nnk., 2019; Trần Lê Đông và nnk., 2019). Với sự trợ giúp của các chuyên gia Liên Xô cũ, đây được coi là bể trầm tích đầu tiên phát hiện ra dầu khí thương mại từ những năm 80 của thế kỷ trước. Dầu khí đã được phát hiện và từng bước được đưa vào khai thác với sản lượng lớn. Cho đến nay, dầu thô khai thác từ bể Cửu Long đã đóng góp tới trên $80 \%$ tổng sản lượng dầu thô của cả nước (Trần Lê Đông và nnk., 2019 ; Vietnam Petroleum Institute, 2011). Tuy nhiên, trong suốt nhiều thập kỷ qua, phần lớn sản lượng dầu khai thác được đều từ trong các vỉa chứa là đá móng granit và granitoid tuổi trước Kainozoi bị nứt nẻ mạnh hoặc trong các vỉa chứa là tầng cát kết tuổi Oligocen - Miocen trong các bẫy cấu tạo truyền thống trong khi các thân cát có tiềm năng đối với bẫy phi cấu tạo gần như chưa được quan tâm nghiên cứu một cách chi tiết.

Một trong những thách thức lớn trong việc tìm kiếm các bẫy phi cấu tạo, ngoài việc đánh giá các điều kiện chắn nóc, chắn đáy và chắn biên ra thì chất lượng thấm, chứa của vỉa chứa rất đáng được quan tâm. Từ trước đến nay, việc nghiên cứu chất lượng vỉa chứa mới chủ yếu dựa trên các thông số vật lý (độ mài tròn, độ chọn lọc, kích thước mảnh vụn,...) và các quá trình địa chất sau trầm tích (quá trình nén chặt, thành đá và biến chất,...) mà ít nghiên cứu đến sự biến đổi về nguồn và hướng vận chuyển trầm tích.

Trong nghiên cứu này, tập thể tác giả sử dụng các số liệu phân tích thành phần mảnh vụn và các tham số vật lý độ hạt trầm tích để đánh giá sự biến đổi nguồn cung cấp vật liệu trầm tích theo không gian và thời gian để dự báo sự biến đổi chất lượng của đá chứa.

\section{Tổng quan về khu vực nghiên cứu}

Khu vực nghiên cứu thuộc lô 09 - 1, nằm về phía đông nam bồn trũng Cửu Long (Hình 1). Đây là một trong những bồn trũng Đệ Tam có triển vọng dầu khí lớn nhất trên thềm lục địa Việt Nam (Trần Lê Đông và nnk., 2019).

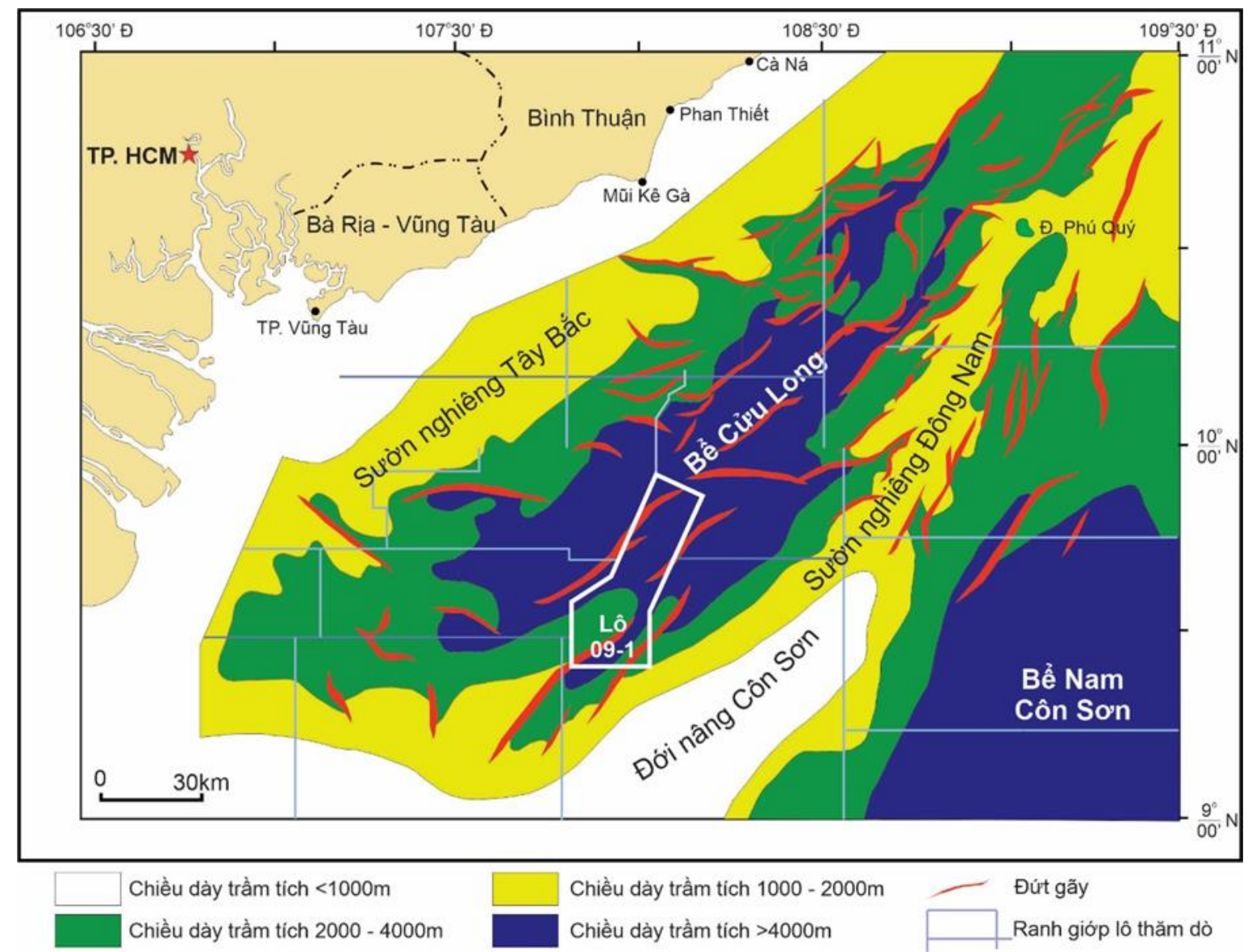

Hình 1. Vị trí địa lý và hình thái cấu trúc khu vực nghiên cúu (Hoàng Ngọc Đông, 2012). 
Phía đông bắc tiếp nối với bể Phú Khánh, sườn tây bắc là vùng biển Đông Nam Bộ, giới hạn phía đông nam được ngăn cách với bể Nam Côn Sơn qua đới nâng Côn Sơn. Bể kéo dài theo hướng đông bắc - tây nam với kích thước $~ 110$ x 360 km, diện tích khoảng $40.000 \mathrm{~km}^{2}$. Kết quả minh giải tài liệu địa chấn $3 \mathrm{D}$ (Hình 2) đã khẳng định bồn trũng Cửu Long là bể kiểu rift sau cung thực thụ được hình thành theo cơ chế tách giãn và phá hủy vỏ lục địa là các thành tạo đá móng trước Kainozoi (Tạ Thị Thu Hoài và Phạm Huy Long, 2009; Lê Văn Cự và nnk., 2019; Schmidt và nnk., 2019; Trần Lê Đông và nnk., 2019).

Những kết quả nghiên cứu về cổ sinh, thành phần thạch học - khoáng vật, địa vật lý giếng khoan và địa chấn địa tầng cho phép phân chia địa tầng của khu vực nghiên cứu thành hai phần chính là: (i) các thành tạo đá móng trước Kainozoi và (ii) các thàng tạo trầm tích Kainozoi (Đỗ Bạt và nnk., 2019; Trần Lể Đông và nnk, 2019). Chi tiết các phân vị địa tầng được tổng hợp trong Hình 3.

\section{Cơ sở tài liệu và phương pháp nghiên cứu}

\subsection{Cơ sở tài liệu}

Để thực hiện nghiên cứu này, tập thể tác giả sử dụng kết quả phân tích độ hạt và thành phần mảnh vụn của 29 mẫu trong giếng khoan "X", và 17 mẫu trong giếng khoan "Y" nằm trong khu vực nghiên cứu (số hiệu giếng khoan đã được mã hóa) (Nguyễn Hoài Chung nnk. 2019a; Nguyễn Hoài Chung và nnk. 2019b). Các mẫu này được phân chia thành 02 tập mẫu đại diện cho cát kết môi trường sông/hồ tuổi Oligocen muộn và cát kết môi trường biển nông tuổi Miocen sớm (Bảng 1).

Bảng 1. Thống kê mẫu vụn trong các giếng khoan sử dụng trong nghiên cúu này.

\begin{tabular}{|c|c|c|c|c|c|}
\hline $\begin{array}{c}\text { Độ sâu } \\
\text { trung } \\
\text { bình } \\
(\mathrm{m})\end{array}$ & Loại mẫu & $\begin{array}{c}\text { Tuổi địa } \\
\text { tầng }\end{array}$ & $\begin{array}{c}\text { Độ sâu } \\
\text { trung } \\
\text { bình } \\
\text { (m) }\end{array}$ & Loại mẫu & $\begin{array}{c}\text { Tuổi địa } \\
\text { tầng }\end{array}$ \\
\hline \multicolumn{3}{|c|}{ Giếng khoan "X" } & 4065 & Mẫu vụn & \multirow{6}{*}{$\begin{array}{c}\text { Oligocen } \\
\text { muộn }\end{array}$} \\
\hline 2525 & Mẫu vụn & \multirow{11}{*}{$\begin{array}{l}\text { Miocen } \\
\text { sớm }\end{array}$} & 4075 & Mẫu vụn & \\
\hline 2535 & Mẫu vụn & & 4085 & Mẫu vụn & \\
\hline 2545 & Mẫu vụn & & 4095 & Mẫu vụn & \\
\hline 2555 & Mẫu vụn & & 4105 & Mẫu vụn & \\
\hline 2565 & Mẫu vụn & & 4115 & Mẫu vụn & \\
\hline 2575 & Mẫu vụn & & \multicolumn{3}{|c|}{ Giếng khoan "Y" } \\
\hline 2585 & Mẫu vụn & & 2775 & Mẫu vụn & Miocen \\
\hline 2595 & Mẫu vụn & & 2785 & Mẫu vụn & \\
\hline 2605 & Mẫu vụn & & 2795 & Mẫu vụn & \\
\hline 2615 & Mẫu vụn & & 2815 & Mẫu vụn & \\
\hline 2625 & Mẫu vụn & & 2825 & Mẫu vụn & \\
\hline 3905 & Mẫu vụn & \multirow{12}{*}{$\begin{array}{c}\text { Oligocen } \\
\text { muộn }\end{array}$} & 2845 & Mẫu vụn & \\
\hline 3915 & Mẫu vụn & & 2855 & Mẫu vụn & \\
\hline 3925 & Mẫu vụn & & 2865 & Mẫu vụn & \\
\hline 3955 & Mẫu vụn & & 2875 & Mẫu vụn & \\
\hline 3965 & Mẫu vụn & & 2885 & Mẫu vụn & \\
\hline 3975 & Mẫu vụn & & 2895 & Mẫu vụn & \\
\hline 3985 & Mẫu vụn & & \begin{tabular}{|l|}
4235 \\
\end{tabular} & Mẫu vụn & \multirow{6}{*}{$\begin{array}{c}\text { Oligocen } \\
\text { muộn }\end{array}$} \\
\hline 3995 & Mẫu vụn & & 4245 & Mẫu vụn & \\
\hline 4005 & Mẫu vụn & & 4255 & Mẫu vụn & \\
\hline 4015 & Mẫu vụn & & 4265 & Mẫu vụn & \\
\hline 4025 & Mẫu vụn & & 4275 & Mẫu vụn & \\
\hline 4055 & Mẫu vụn & & 4285 & Mẫu vụn & \\
\hline
\end{tabular}

\section{$\underline{E N}$}

Sườn nghiêng $\boxminus \mathrm{N} /$ Đới nâng Côn Sơn

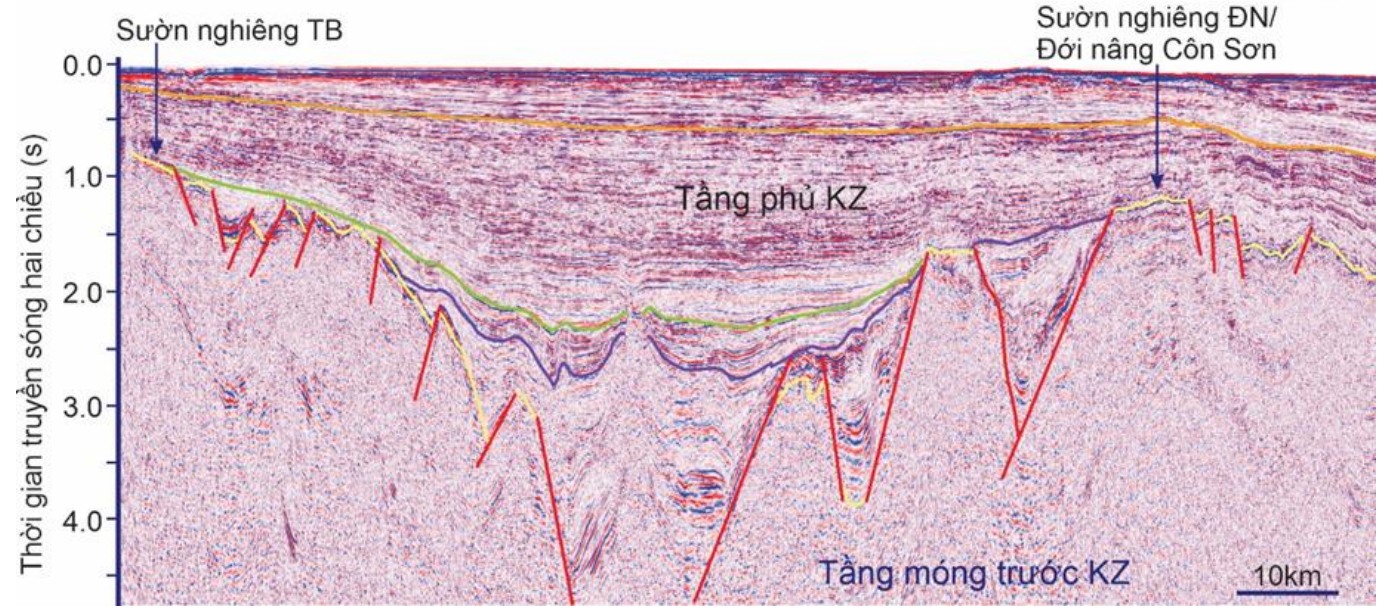

Hình 2. Mặt cắt địa chấn phương tây bắc - đông nam cắt qua trục bồn trũng Cửu Long thể hiện đá móng trước Kainozoi (KZ) bị phá hủy bởi hệ thống các đứt gãy tách giãn kiểu rift. 


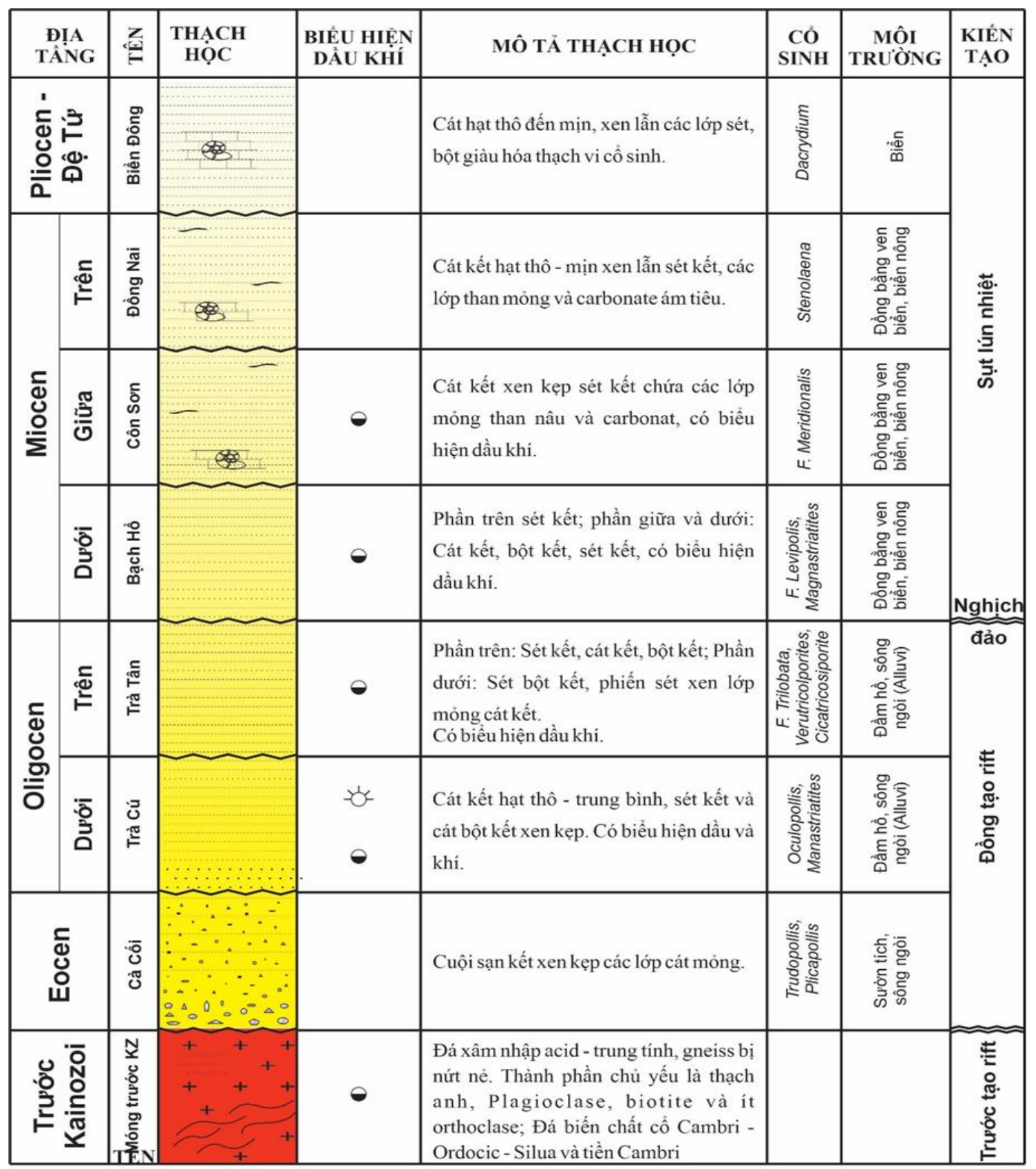

Hình 3. Cột địa tầng tổng hợp của khu vực nghiên cứu (Đỗ Bạt và nnk. 2019, Trần Lê Đông và nnk. 2019).

Ngoài ra, tập thể tác giả còn tái xử lý các kết quả phân tích cổ sinh, kết quả nghiên cứu tướng và môi trường trầm tích, cũng như kết quả minh giải địa chấn địa tầng của khu vực (Nguyễn Hoài Chung và nnk., 2019a, b).

\subsection{Phương pháp nghiên cứu}

\subsubsection{Phưong pháp phân tích độ hạt và các tham số vật lý của trầm tích}

Mẫu vụn trầm tích sau khi được lấy từ bể lắng dung dịch bơm từ giếng khoan được tiến hành gia công sơ bộ, sấy khô và cân trọng lượng trước khi tiến hành sàng rây ở các cấp hạt khác nhau.Phần trăm trọng lượng của các cấp hạt sau đó được đưa vào xử lý thống kê bằng phần mềm Gradistat phiên bản 9.1 được viết bởi Simon Blott (Blott và Pye, 2001). Các giá trị kích thước hạt trung bình (mean), độ chọn lọc (So), độ lệch (Sk), độ nhọn $\left(\mathrm{K}_{\mathrm{G}}\right)$ cũng như tên và kiến trúc trầm tích được tính toán theo 
phương pháp hình học của Folk và Ward năm 1957 (Folk, 1954; Folk và Ward, 1957) và được trình bày trong Bảng 2.

Độ mài tròn (Ro) của các mảnh vụn sẽ được đo trực tiếp và tính toán giá trị tỉ số trục dài/trục ngắn của mỗi mảnh vụn theo các tiêu chuẩn được trình bày trong Bảng 3 .

\subsubsection{Phương pháp phân tích thành phần vật chất}

Phương pháp phân tích thạch học được tiến hành để xác định thành phần thạch học và thành phần khoáng vật của đá. Phương pháp này có thể được thực hiện bằng quan sát trực tiếp mảnh vụn trầm tích lấy lên từ mùn khoan (mẫu cutting) dưới kính loup hoặc kính hiển vi để đánh giá sơ bộ về thành phần và kiến trúc trầm tích. Tuy nhiên, hạn chế của phương pháp này là mang tính định tính nhiều hơn, mẫu lẫy từ mùn khoan nên sự hỗn nhiễm cao. Để phân tích có tính định lượng, các mẫu trầm tích được phân tích dưới dạng lát mỏng thạch học tự nhiên hoặc nhân tạo. Đối với mẫu lát mỏng nhân tạo, các mảnh vụn trầm tích lấy từ mùn giếng khoan sẽ được rửa sạch
Bảng 2. Các tiêu chuẩn phân bố thống kê của trầm tích (Folk, 1954; Folk và Ward, 1957).

\begin{tabular}{|c|c|c|}
\hline Thông số & Giá trị & Nhận xét \\
\hline \multirow{4}{*}{$\begin{array}{c}\text { Độ chọn lọc } \\
\text { So }\end{array}$} & $<1,27$ & Rất tốt \\
\cline { 2 - 3 } & $1,27 \div 1,41$ & Tốt \\
\cline { 2 - 3 } & $1,41 \div 1,62$ & Tương đối tốt \\
\cline { 2 - 3 } & $1,62 \div 2,00$ & Trung bình \\
\cline { 2 - 3 } & $2,00 \div 4,00$ & Kém \\
\cline { 2 - 3 } Độ lệch Sk & $4,00 \div 16,00$ & Rất kém \\
\cline { 2 - 3 } & $>16,00$ & Cực kỳ kém \\
\hline & $\div 0,3 \div \div 1,0$ & Lệch rất ít \\
\cline { 2 - 3 } & $\div 0,1 \div 0,3$ & Lếch ít \\
\cline { 2 - 3 } & $\div 0,1 \div+0,1$ & Đối xứng \\
\cline { 2 - 3 } & $+0,1 \div+0,3$ & Lệch nhiều \\
\hline \multirow{4}{*}{ Độ nhọn $K_{G} G$} & $+0,3 \div+0,1$ & Lệch rất nhiều \\
\cline { 2 - 3 } & $<0,67$ & Rất phẳng \\
\cline { 2 - 3 } & $0,67 \div 0,90$ & Phẳng \\
\cline { 2 - 3 } & $0,90 \div 1,11$ & T, đối phẳng \\
\cline { 2 - 3 } & $1,11 \div 1,50$ & Nhọn \\
\cline { 2 - 3 } & $1,50 \div 3,00$ & Rất nhọn \\
\hline
\end{tabular}

Bảng 3. Kết quả phân tích độ hạt trầm tích trong giếng khoan của khu vực nghiên cứu.

\begin{tabular}{|c|c|c|c|c|c|c|}
\hline Độ sâu trung bình (m) & Kích thước hạt trung bình - TB (micron) & \multicolumn{2}{c|}{ So } & \multicolumn{2}{c|}{ Sk } & \multicolumn{2}{c|}{$K_{G}$} & \multicolumn{2}{c|}{ Ro Tuổi địa tầng } \\
\hline \multicolumn{2}{|c|}{ Giếng khoan "X" } \\
\hline 2525 & 424,12 & 2,16 & $-0,46$ & 0,99 & 0,69 & \\
\hline 2535 & 458,97 & 2,24 & $-0,28$ & 1,46 & 0,70 \\
\hline 2545 & 427,38 & 2,20 & $-0,14$ & 0,92 & 0,68 \\
\hline 255 & 428,38 & 2,26 & $-0,28$ & 1,06 & 0,70 \\
\hline 2565 & 418,25 & 2,18 & $-0,05$ & 1,06 & 0,69 \\
\hline 2575 & 419,54 & 2,29 & $-0,33$ & 1,17 & 0,70 \\
\hline 2585 & 433,47 & 2,13 & $-0,35$ & 1,00 & 0,70 \\
\hline 2595 & 451,72 & 2,25 & $-0,38$ & 0,79 & 0,69 \\
\hline 2605 & 438,99 & 2,24 & $-0,14$ & 1,02 & 0,70 \\
\hline 2615 & 425,16 & 2,25 & $-0,43$ & 1,19 & 0,68 \\
\hline 2625 & 450,21 & 2,20 & $-0,39$ & 0,97 & 0,68 \\
\hline Min & 418,25 & 2,13 & $-0,46$ & 0,79 & 0,68 \\
\hline Max & 458,97 & 2,29 & $-0,05$ & 1,46 & 0,70 \\
\hline TB & 434,20 & 2,22 & $-0,29$ & 1,06 & 0,69 \\
\hline 3905 & 78,30 & 1,42 & 0,08 & 1,12 & 0,71 \\
\hline 3915 & 130,21 & 1,39 & $-0,16$ & 1,19 & 0,70 \\
\hline 3925 & 80,13 & 1,51 & 0,03 & 1,22 & 0,71 \\
\hline 3955 & 81,56 & 1,53 & $-0,22$ & 0,96 & 0,67 \\
\hline 3965 & 103,10 & 1,49 & $-0,02$ & 1,16 & 0,70 \\
\hline 3975 & 99,86 & 1,45 & $-0,09$ & 1,16 & 0,62 \\
\hline 3985 & 101,47 & 1,42 & 0,02 & 0,79 & 0,70 \\
\hline 3995 & 94,70 & 1,51 & $-0,16$ & 0,96 & 0,61 \\
\hline 4005 & 84,94 & 1,41 & $-0,12$ & 1,01 & 0,62 & \\
\hline & & & & \\
\hline & & &
\end{tabular}




\begin{tabular}{|c|c|c|c|c|c|c|}
\hline Độ sâu trung bình (m) & Kích thước hạt trung bình - TB (micron) & So & Sk & $\mathrm{K}_{\mathrm{G}}$ & Ro & Tuổi địa tầng \\
\hline 4015 & 92,83 & 1,42 & $-0,07$ & 1,00 & 0,62 & \\
\hline 4025 & 102,51 & 1,41 & 0,00 & 0,92 & 0,59 & \\
\hline 4055 & 91,50 & 1,70 & $-0,14$ & 1,04 & 0,58 & \\
\hline 4065 & 148,32 & 1,44 & $-0,05$ & 0,78 & 0,58 & \\
\hline 4075 & 127,39 & 1,33 & $-0,07$ & 0,99 & 0,70 & \\
\hline 4085 & 124,18 & 1,34 & 0,07 & 0,99 & 0,69 & \\
\hline 4095 & 113,13 & 1,59 & $-0,01$ & 1,00 & 0,59 & \\
\hline 4105 & 108,28 & 1,52 & 0,03 & 0,97 & 0,58 & \\
\hline 4115 & 114,65 & 1,43 & 0,04 & 1,03 & 0,58 & \\
\hline Min & 78,30 & 1,33 & $-0,22$ & 0,78 & 0,58 & \\
\hline Max & 148,32 & 1,70 & 0,08 & 1,22 & 0,71 & \\
\hline TB & 104,28 & 1,46 & $-0,05$ & 1,02 & 0,64 & \\
\hline \multicolumn{7}{|c|}{ Giếng khoan "Y" } \\
\hline 2775 & 424,23 & 2,08 & $-0,26$ & 0,95 & 0,37 & \multirow{14}{*}{ Miocen sớm } \\
\hline 2785 & 417,25 & 2,12 & $-0,39$ & 0,74 & 0,36 & \\
\hline 2795 & 457,31 & 2,09 & $-0,27$ & 1,02 & 0,47 & \\
\hline 2815 & 501,88 & 2,12 & 0,05 & 1,21 & 0,46 & \\
\hline 2825 & 471,34 & 2,23 & $-0,15$ & 0,80 & 0,44 & \\
\hline 2845 & 306,87 & 2,08 & $-0,24$ & 0,74 & 0,42 & \\
\hline 2855 & 425,91 & 2,07 & $-0,34$ & 0,90 & 0,39 & \\
\hline 2865 & 259,75 & 2,03 & $-0,22$ & 0,97 & 0,42 & \\
\hline 2875 & 273,47 & 2,08 & $-0,32$ & 0,92 & 0,44 & \\
\hline 2885 & 419,25 & 2,27 & $-0,49$ & 1,03 & 0,43 & \\
\hline 2895 & 208,16 & 2,05 & $-0,09$ & 0,81 & 0,46 & \\
\hline Min & 208,16 & 2,03 & $-0,49$ & 0,74 & 0,36 & \\
\hline Max & 501,88 & 2,27 & 0,05 & 1,21 & 0,47 & \\
\hline TB & 378,67 & 2,11 & $-0,25$ & 0,92 & 0,42 & \\
\hline 4235 & 425,60 & 2,15 & $-0,50$ & 0,98 & 0,49 & \multirow{9}{*}{$\begin{array}{l}\text { Oligocen } \\
\text { muộn }\end{array}$} \\
\hline 4245 & 416,64 & 2,14 & $-0,35$ & 0,94 & 0,52 & \\
\hline 4255 & 240,98 & 2,07 & $-0,25$ & 1,07 & 0,56 & \\
\hline 4265 & 153,10 & 1,67 & $-0,02$ & 1,14 & 0,53 & \\
\hline 4275 & 234,61 & 2,05 & $-0,24$ & 0,87 & 0,48 & \\
\hline 4285 & 433,19 & 2,05 & $-0,49$ & 1,20 & 0,56 & \\
\hline Min & 153,10 & 1,67 & $-0,50$ & 0,87 & 0,48 & \\
\hline Max & 433,19 & 2,15 & $-0,02$ & 1,20 & 0,56 & \\
\hline TB & 317,35 & 2,02 & $-0,31$ & 1,03 & 0,52 & \\
\hline
\end{tabular}

và gắn kết lại bằng keo chuyên dụng trước khi tiến hành mài mỏng và phân kích dưới kính hiển vi phân cực với độ phân giải cao. Dưới kính hiển vi, ngoài việc xác định chi tiết thành phần khoáng vật chính và khoáng vật phụ, còn xác định tỷ phần tương đối của 3 hợp phần chính là thạch anh, felspat và mảnh đá có mặt trong trầm tích để làm cơ sở cho luận giải nguồn gốc vật liệu sau này.

\section{Kết quả}

\subsection{Kết quả phân tích các tham số vật lý của trầm tích}

Kết quả phân tích thành phần độ hạt được trình bày trong Bảng 3 và các Hình 4,5 . Có thể dễ dàng nhận thấy, kích thước hạt vụn có sự thay đổi đáng kể theo tuổi địa tầng và vị trí lấy mẫu ở hai giếng khoan khác nhau.

Bảng 3 và Hình 4 thể hiện kết quả phân tích độ hạt và các tham số vật lý trầm tích của các mẫu lấy trong giếng khoan " $\mathrm{X}$ " ở hai khoảng tuổi khác nhau là Miocen sớm (ở độ sâu $2.525 \div 2.625 \mathrm{~m}$ ) và Oligocen muộn (ở độ sâu 3.905 4.115 m). Các mẫu trầm tích tuổi Miocen ở giếng khoan "X" có kích thước hạt thay đổi từ 418,25 458,97 micron, trung 
bình 434,2 micron và được phân loại vào nhóm trầm tích cát hạt trung; độ chọn lọc thay đổi từ $2,13 \div 2,29$, trung bình 2,22 , thuộc nhóm trầm tích có độ chọn lọc kém; hệ số bất đối xứng có giá trị trong khoảng từ $-0,46 \div-0,05$, trung bình $-0,29$; có đặc điểm phân bố lệch trái; độ nhọn dao động từ $0,79 \div 1,46$, trung bình 1,06 , cho thấy biểu đồ phân bố độ hạt tương đối phẳng. Độ mài tròn của các mảnh vụn nằm trong khoảng $0,68 \div 0,70$, trung bình 0,69 ; nằm trong nhóm có độ mài tròn ở mức trung bình khá. Trong khi đó, các mẫu trầm tích tuổi Oligocen muộn của cùng giếng khoan " $\mathrm{X}$ " được đặc trưng bởi các thông số độ hạt sau: kích thước hạt trung bình (mean): 78,30 $\div 148,32$ micron, trung bình 104,28 micron, thuộc nhóm cát hạt mịn đến rất mịn. Độ chọn lọc (So): 1,33 1,70 , trung bình 1,46; tương ứng với độ chọn lọc tương đối tốt đến tốt; độ lệch (Sk) $-0,22 \div 0,08$, trung bình 0,05 , thể hiện phân bố lệch ít đến đối xứng; độ nhọn $\left(\mathrm{K}_{\mathrm{G}}\right)$ : $0,78 \div 1,22$, trung bình 1,02 , phân bố đỉnh phẳng đến tương đối phẳng. Độ mài tròn (Ro): $0,58 \div 0,71$, trung bình 0,64 , cho thấy trầm tích có độ mài tròn tốt đến rất tốt.

Tại giếng khoan "Y”, các tham số độ hạt có đặc điểm phân bố trên phổ rộng hơn (Bảng 3, Hình 5). Các mẫu trầm tích tuổi Miocen sớm trong giếng khoan này có độ hạt trung bình (mean): 208,16 $\div 501,88$ micron, trung bình 378,67 micron, thuộc nhóm cát hạt trung bình. Độ chọn lọc (So) thay đổi từ $2,03 \div-2,27$, trung bình 2,11 , cho thấy

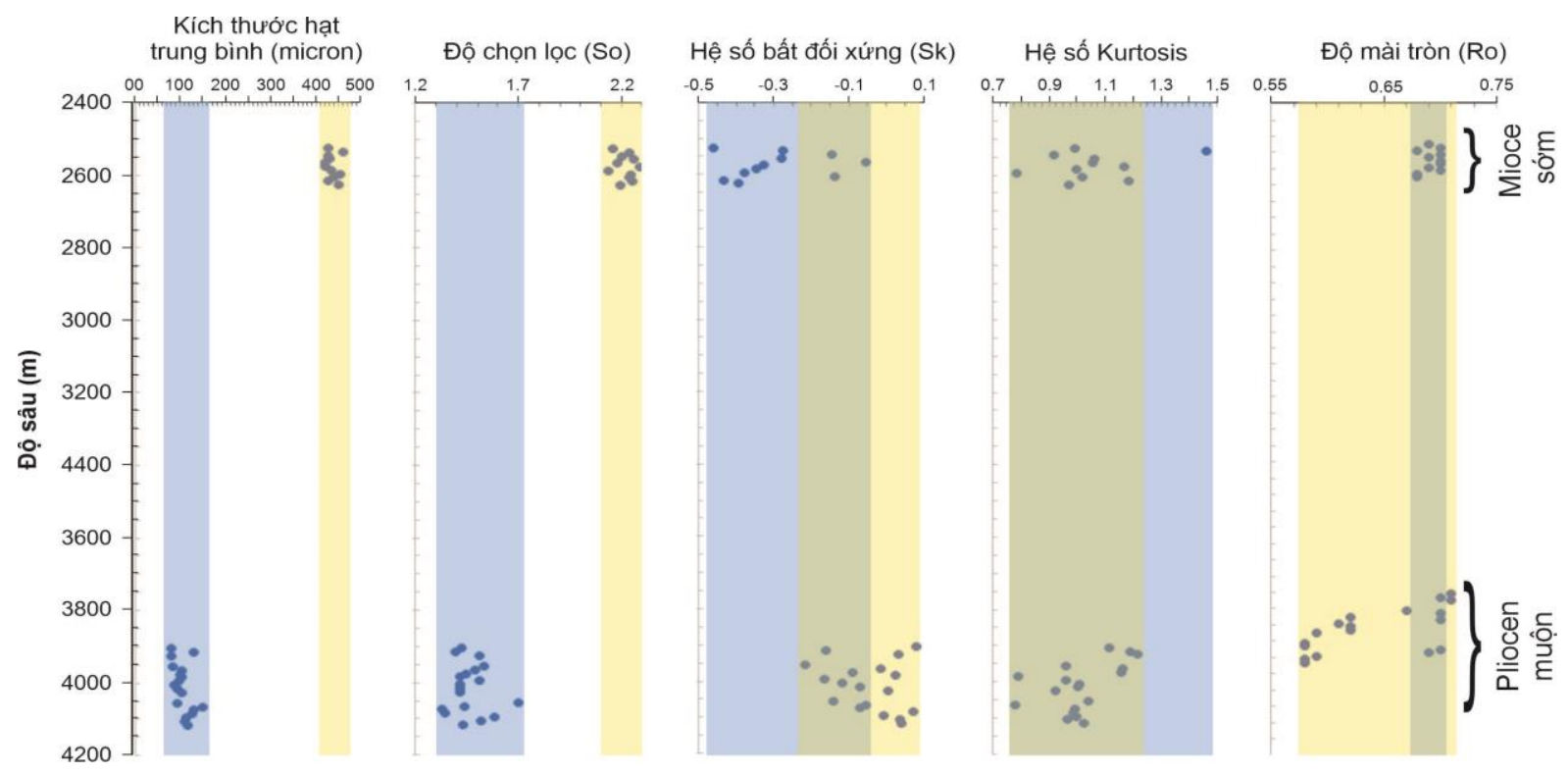

Hình 4. Biểu đồ phân tích độ hạt trầm tích tại giếng khoan "X".
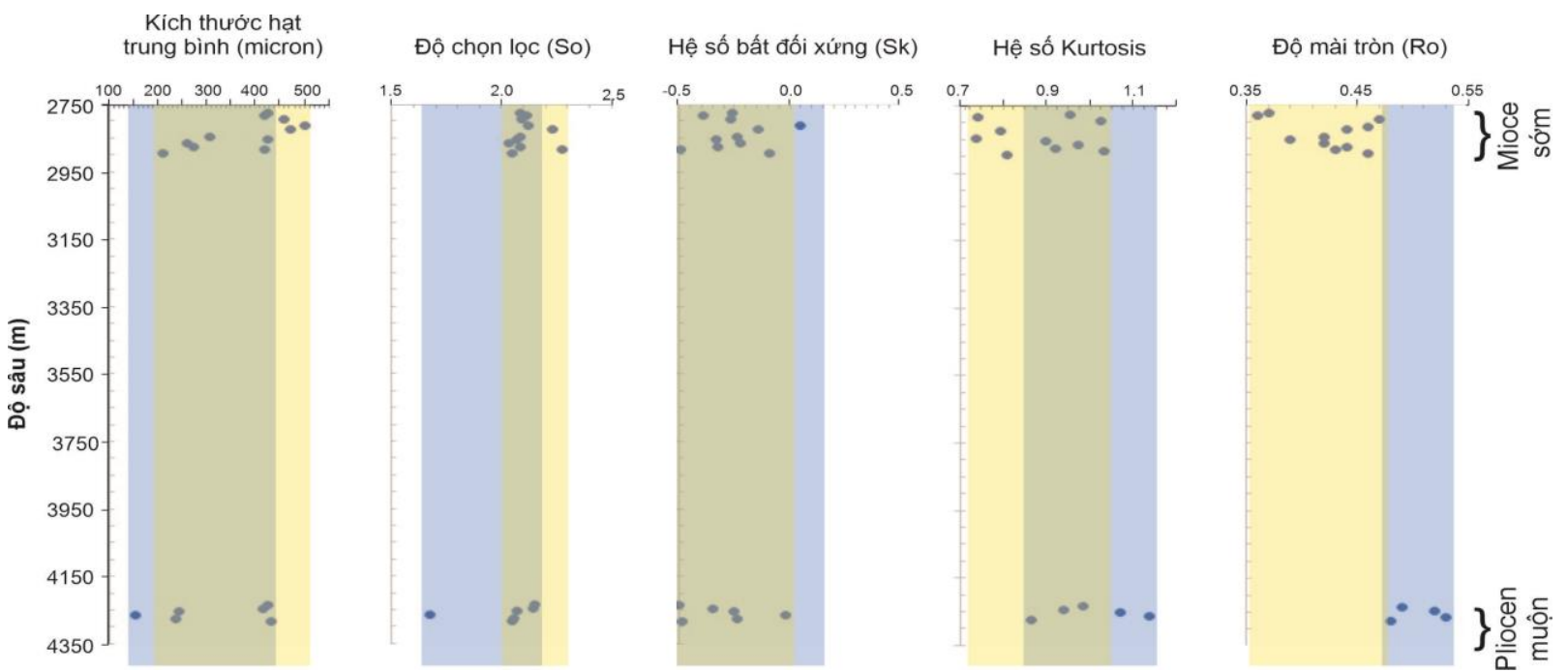

Hình 5. Biểu đồ phân tích độ hạt trầm tích tại giếng khoan " $Y$ ". 
chúng có mức độ chọn lọc kém; độ lệch (Sk) dao động từ $-0,49 \div 0,05$, trung bình $-0,25$, cho thấy độ hạt phân bố trên dải rộng từ lệch ít đến lệch trái nhiều; độ nhọn $\left(\mathrm{K}_{\mathrm{G}}\right): 0,74 \div 1,21$, trung bình 0,92 , thể hiện cực trị phân bố độ hạt có đỉnh bằng đến tương đối bằng. Độ mài tròn (Ro) thay đổi từ $0,36 \div 0,47$, trung bình 0,42 , phản ánh các mảnh vụn trầm tích có độ mài tròn trung bình. Cũng trong giếng khoan Y, các mẫu trầm tích tuổi Oligocen muộn có kích thước hạt trung bình từ 153,10 433,19 micron; trung bình 317,35 micron và thuộc nhóm cát hạt mịn đến trung bình. Độ chọn lọc So: $1,67 \div 2,15$; trung bình 2,02, tương ứng với trầm tích có độ chọn

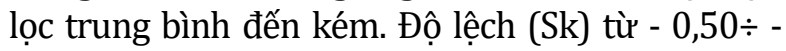
0,02 , trung bình $-0,31$, tương úng với phân bố lệch rất ít đến ít. Độ nhọn $\left(\mathrm{K}_{\mathrm{G}}\right): 0,87 \div 1,20$, trung bình 1,03, cho thấy biểu đồ phân bố độ hạt có cực trị thay đổi từ phân bố phẳng đến nhọn. Độ mài tròn (Ro): $0,48 \div 0,56$, trung bình 0,52 , tương ứng với trầm tích có độ mài tròn trung bình đến tương đối tốt.

\subsection{Kết quả phân tích thành phần khoáng vật}

Giếng khoan "X": Kết quả phân tích lát mỏng thạch học của 29 mẫu vụn cho thấy: trong khoảng độ sâu $2.525 \div 26.20 \mathrm{~m}$ (tuổi Miocen sớm), thành phần chủ yếu cát kết hạt thô và hạt vụn bở rời với ít mảnh sét kết và vài mảnh calcit. Trong khi đó, ở khoảng độ sâu 3.905 4.110 m (tuổi Oligocen muộn) phổ biến là cát kết hạt rất mịn - mịn và hạt vụn bở rời, kế đó là sét kết nâu vàng, bột kết và một lượng nhỏ là mảnh calcit (các Hình 6, 7). Mẫu cát kết chứa nhiều vật liệu sét đồng trầm tích (>15\%).

Kết quả phân tích thành phần mảnh vụn trong các Hình 6 và 7 cho thấy, đại đa số các mẫu cát kết đều rơi vào trường cát kết arkose.

Giếng khoan "Y": Kết quả phân tích lát mỏng thạch học của mẫu vụn cho thấy, trong khoảng độ sâu $2.775 \div 2.895 \mathrm{~m}$, thành phần chủ yếu cát kết hạt thô và hạt vụn bở rời với ít mảnh sét kết và vài mảnh calcit.

Trong khi đó, ở khoảng độ sâu 4.235 4.285 m phần lớn là sét kết (quan sát bằng mắt thường) với ít cát kết hạt trung bình - thô, cát kết hạt rất mịn mịn, kế đó là hạt vụn bở rời và bột kết (các Hình 8 , 9). Sét kết ở đây có màu nâu vàng - nâu đỏ.

Từ Hình 9, có thể dễ dàng nhận thấy các mẫu cát kết trong giếng khoan $\mathrm{Y}$ đều hoàn toàn nằm trong trường cát kết arkose.

\section{Thảo luận về biến đổi nguồn trầm tích và chất lượng đá chứa}

Tại giếng khoan "X", đặc tính trầm tích có sự khác biệt rõ rệt giữa hai khoảng tuổi Oligocen muộn và Miocen sớm. Có thể dễ dàng nhận thấy các

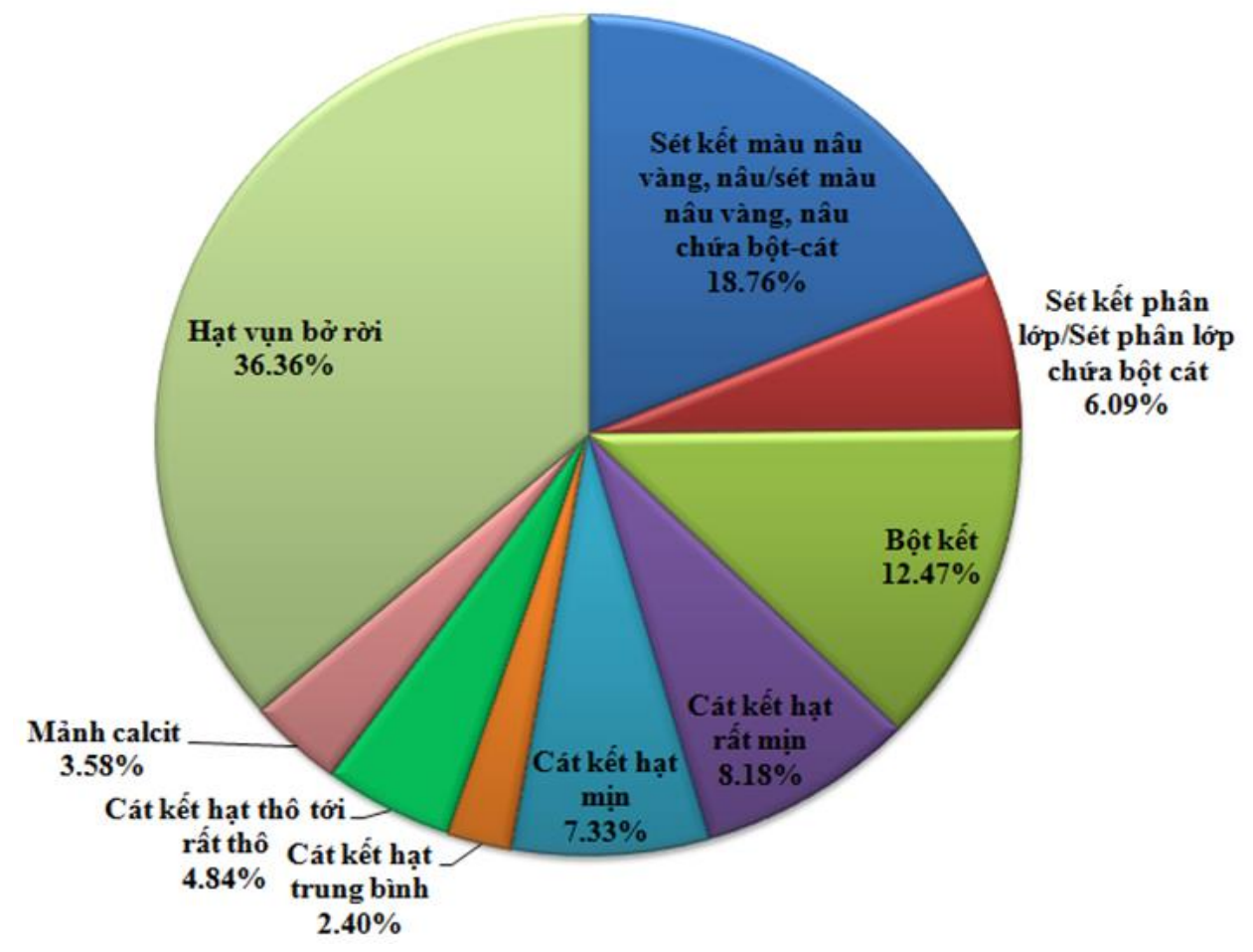

Hình 6. Thành phần mảnh vụn trong mẫu cát kết giếng khoan "X". 


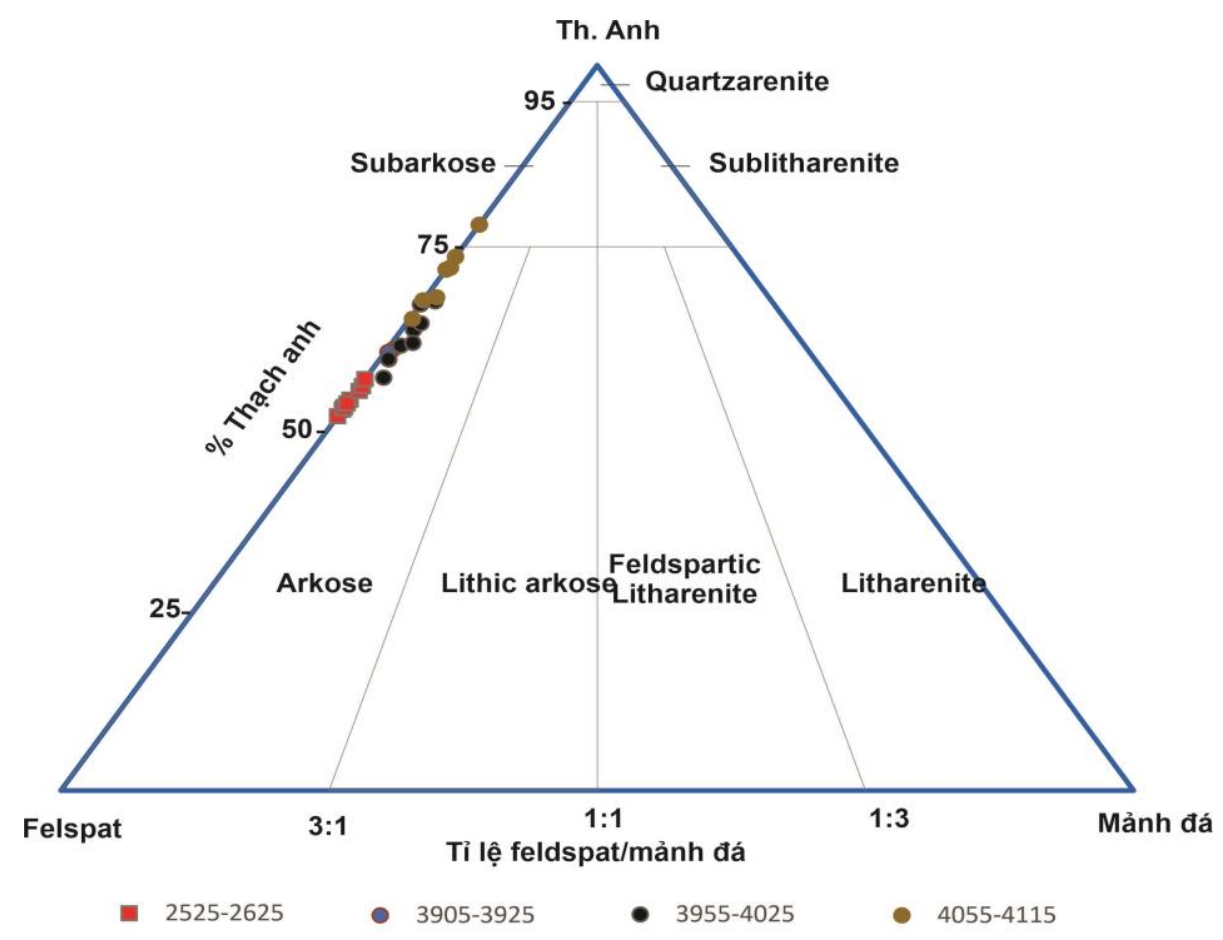

Hình 7. Biểu đồ phân loại cát kết 3 hợp phần (Thạch anh - Felspat - mảnh đá) trong giếng khoan "X" (Dickinson và Suczek, 1979).

mẫu cát tuổi Oligocen muộn có kích thước hạt nhỏ hơn rất nhiều so với các mẫu cát tuổi Miocen sớm.

Tương tự như vậy, cát kết tuổi Oligocen muộn có độ chọn lọc kém hơn hệ số bất đối xứng thể hiện độ lệch phải (dương) nhiều hơn và độ mài tròn thay đổi trong khoảng rộng hơn so với cát kết tuổi Miocen muộn (Hình 4). Duy nhất chỉ có độ nhọn có giá trị tương đối giống nhau. Điều này được lý giải do sự thay đổi về nguồn trầm tích khi có sự chuyển dịch môi trường lắng đọng từ mô trường sông/hồ (Oligocen muộn) sang môi trường biển (Miocen sớm). Trầm tích Miocen hình thành trong môi trường biển có sự tham gia của nhiều nguồn cung cấp hơn và bị chi phối bởi các yếu tố dòng hải lưu ven bờ, sóng, thủy triểu nên chúng có độ chọn lọc tốt hơn.

Hình 5 cho thấy một bức tranh hoàn toàn khác đối với các mẫu cát kết trong giếng khoan "Y". Về cơ bản, các tham số vật lý của các mẫu cát kết tuổi Oligocen muộn và Miocen sớm trong giếng khoan "Y" không thay đổi nhiều theo thời gian, mặc dù kích thước hạt của trầm tích Miocen có sự gia tăng tỷ phần hạt thô hơn đôi chút. Tuy nhiên, độ mài tròn của cát kết Miocen sớm trong giếng khoan này lại thấp hơn đáng kể so với cát kết tuổi Oligocen muộn. Điều này cho thấy sự gia tăng lượng hạt thô cùng với độ mài tròn kém hơn có thể là những chỉ dấu cho biết trầm tích Miocen sớm trong giếng khoan Y được cung cấp một lượng đáng kể từ các nguồn địa phương hơn.

Biểu đồ thạch địa hóa (Hình 10) dựa trên ba hợp phần chính là thạch anh, felspat và mảnh đá cho thấy, nguồn trầm tích chủ yếu được cung cấp do quá trình bóc mòn từ các thành tạo đá gốc thuộc miền vỏ lục địa chuyển tiếp (Dickinson và nnk. 1983). Sự thay đổi về thông số độ hạt, nguồn trầm tích theo thòi gian và không gian giữa hai giếng khoan có tác động đến độ rỗng, độ thấm của tầng chứa cát kết trong khu vực nghiên cứu.

\section{Tại giếng khoan " $X$ "}

Độ rỗng của cát kết tuổi Miocen sóm không tốt, do phần lớn các lỗ rỗng đã bị trám bởi vật chất đồng trầm tích. Rất hiếm lỗ rỗng giữa các hạt còn sót lại trong cát kết greywack, ít rỗng trong hạt felspat bị hòa tan và ít vi lỗ rỗng trong những đám sét. Trong khi đó, độ rỗng của cát kết tuổi Oligocen muộn ở mức trung bình - trung bình tốt (trung bình $4 \div 5 \%$, đôi khi $11,4 \%$ ).

Độ rỗng chủ yếu là rỗng giưa các hạt và một phần gia tăng bởi độ rỗng trong hạt do sự hòa tan các khoáng vật không bền vững (Nguyễn Hoài Chung và nnk., 2019a, b). 


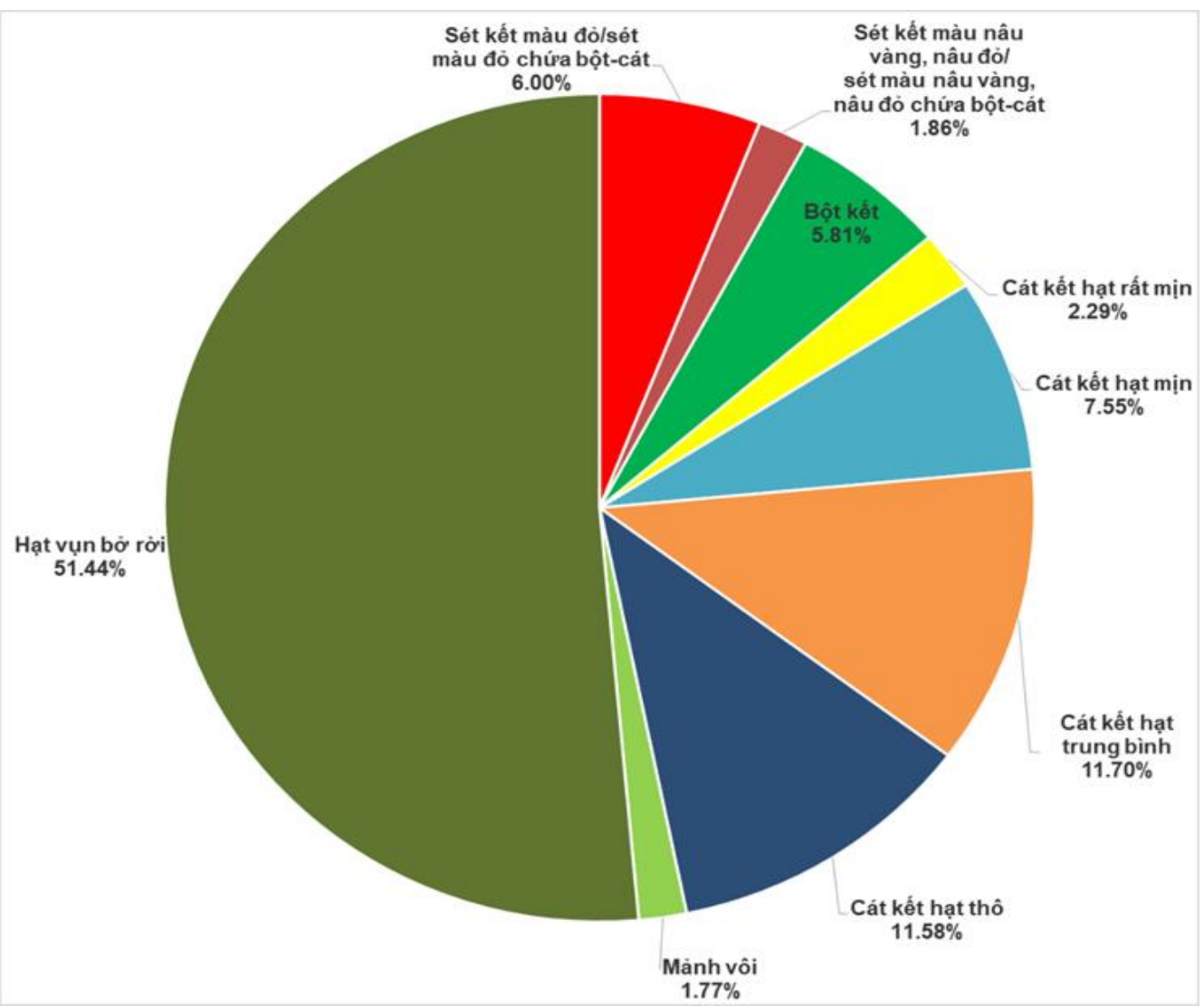

Hình 8. Thành phần mảnh vụn trong mẫu cát kết giếng khoan "Y".

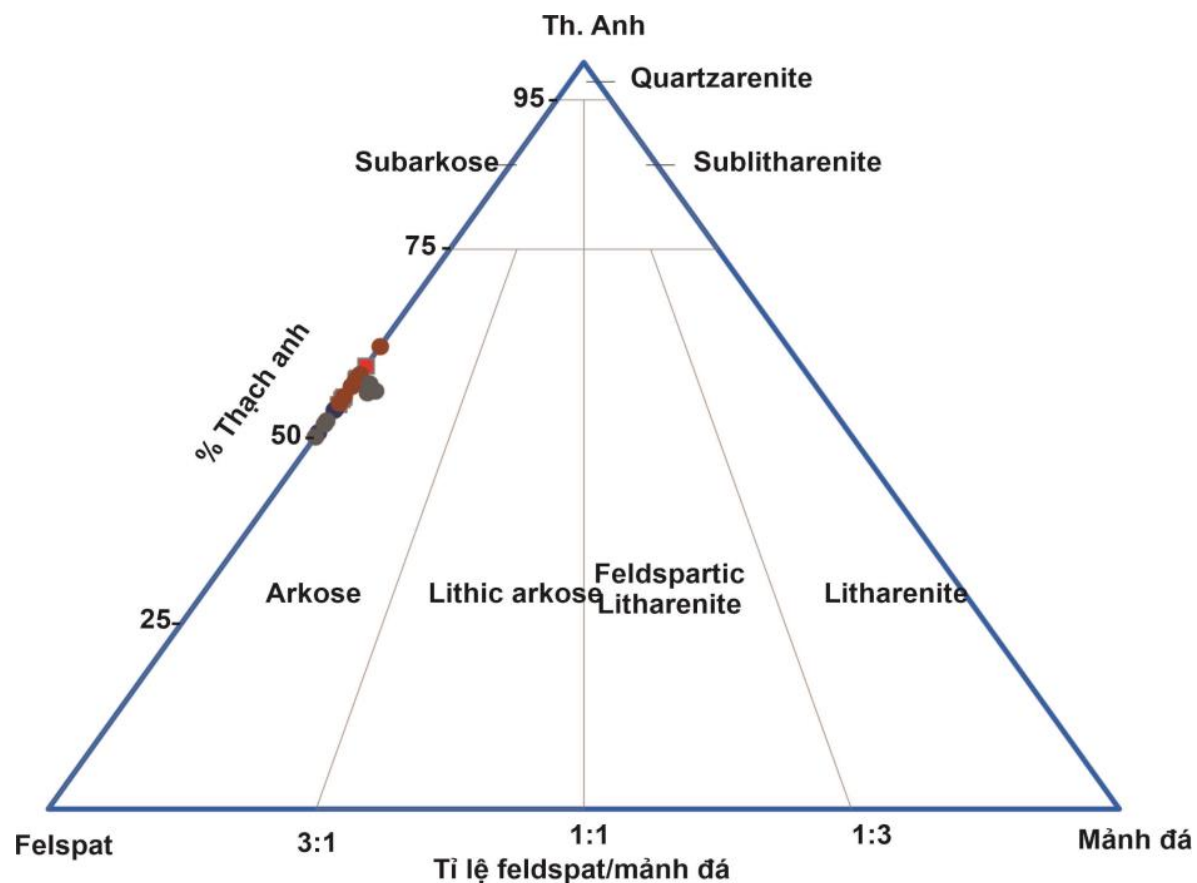

- 2770-2830

- 2840-2900

- 2910-2970

- $4230-4290$

Hình 9. Biểu đồ phân loại cát kết 3 hợp phần (Thạch anh - Felspat - mảnh đá) trong giếng khoan "Y" (Dickinson và Suczek, 1979). 

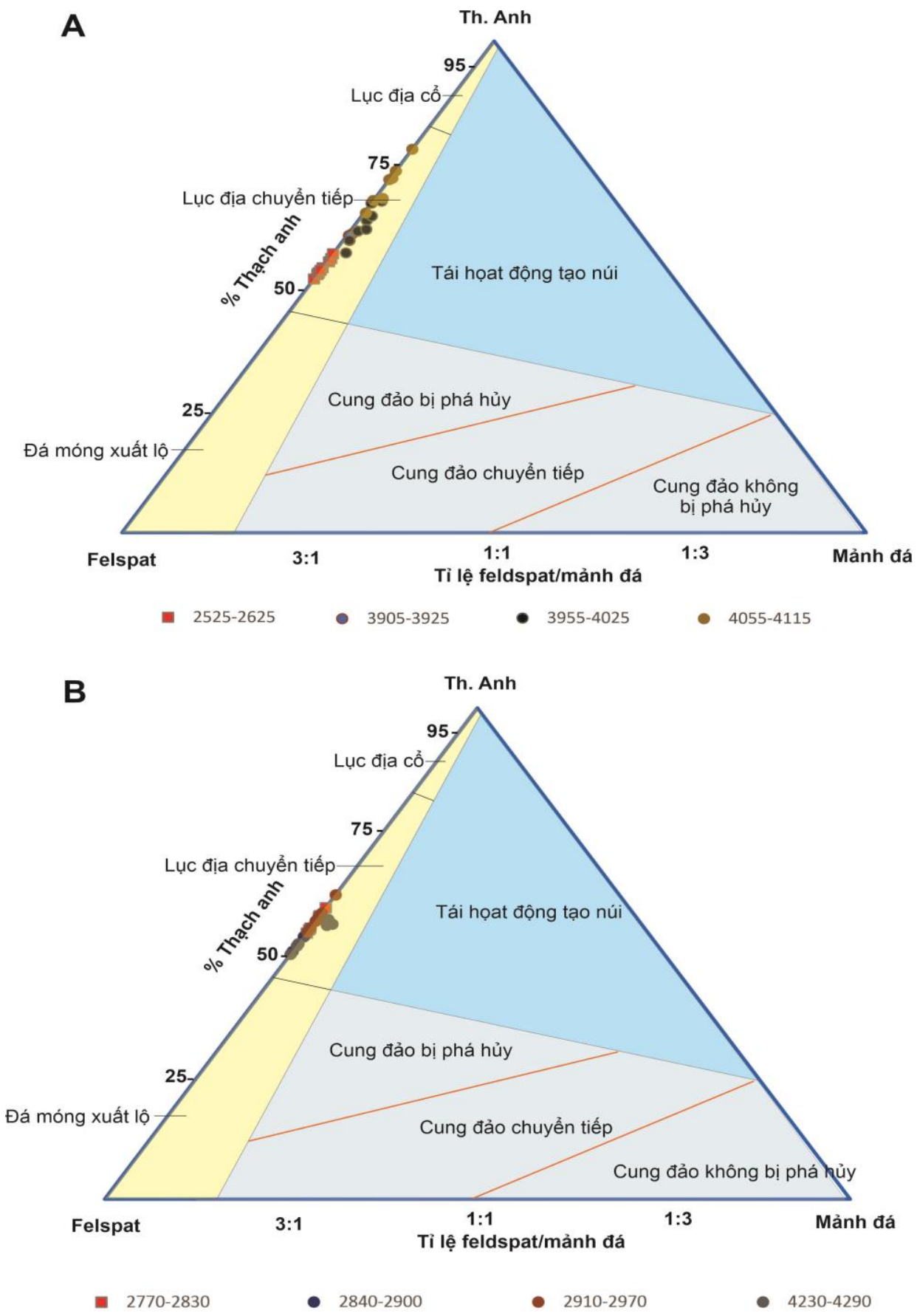

Hình 10. Biểu đồ thạch địa hóa xác định nguồn trầm tích theo Dickinson và nnk. (1983).

\section{Tạigiếng khoan " $Y$ "}

Độ rỗng của cát kết tuổi Miocen sớm không tốt, do phần lớn các lỗ rỗng đã bị lấp đầy bởi vật chất đồng trầm tích. Rất hiếm lỗ rỗng giữa các hạt còn sót lại trong cát kết greywack, ít rỗng trong hạt feldspat bị hòa $\tan (0,4 \div 1,0 \%)$ và ít vi lỗ rỗng trong những đám sét. Tương tự như vậy, độ rỗng của cát kết tuổi Oligocen muộn cũng không được tốt. Độ rỗng chủ yếu là rỗng giữa các hạt và một phần gia tăng bởi độ rỗng do sự hòa tan các khoáng vật không bền vững. Hình 5 cho thấy, độ rỗng nguyên sinh của cát kết trong khoảng $4.230 \div 4.290 \mathrm{~m}$ bị giảm do quá trình nén ép là $~ 30 \div 50 \%$ và do quá trình xi măng là $50 \div 60 \%$. Độ rỗng của tầng chứa oligocen trong giếng khoan này không tốt bằng giếng khoan " $\mathrm{X}$ ", 
co the la do vi trı gieng khoan đat gan nguon vat lieu, cac manh vun co đo mai tron kem hơn nên cac manh vun nho lap nhet vao khoang trong giư cac manh vun lơn lam giam đo rong va đo tham cua via chưa.

\section{Kết luận}

Tư nhưng ket qua nghiên cưu thach hoc tram tıch nêu trên, có thể rut ra đước mot so ket luan chinh sau:

- Khu vưc nghiên cưu co môi trương tram tıch tương đoi phưc tap, thay đoi tư môi trương sông ho trong Oligocen sang môi trương bien nông trong Miocen som.

- Ket qua phân tich thanh phan manh vun va tham so vat ly tram tich cho thay co sư thay doi nguon vat lieu giưa hai giai đoan Oligocen sơm va Miocen muon ơ gieng khoan " $\mathrm{X}$ ", vori su tham gia nhieu hơn cua cat hat thô va anh hương cua yeu to song, thuy triều, cac dong hai luu, lam cho thanh phan manh vun co đo chon loc va mai tron tot hơn. Ngươc lai, gieng khoan "Y" không cho thay sư thay đoi đang ke nao ve thanh phan đo hat va cac tham so vat ly đo hat. Tuy nhiên, co sư gia tăng nhe ve thanh phan cat hat thô trong cat ket Miocen sơm vơi đo mai tron kem hơn so voi tang cat ket Oligocen muon do co sư tham gia cua yeu to nguon cung cap vat lieu tram tich đia phương tư cac khoi lân can.

- So sanh giưa hai gieng khoan co the thay gieng khoan " $\mathrm{X}$ " co thanh phan manh vun it hơn va thanh phan khoang vat set cao hơn so vơi gieng khoan Y (các Hınh 6, 8), sư khac biet nay co the đươc giai thıch do vi tri gieng khoan " $\mathrm{X}$ " nam xa cac nguon đia phương hơn so vơi gieng khoan " $Y$ ".

- Nhưng thay đoi ve nguon va tham so đo hat tram tich co vai tro quan trong đoi vơi chat lương đa chưa trong khu vưc. Ket qua nghiên cưu đa cho thay tap cat ket tuoi Miocen sơm co chat lương (đo rong) kem hơ so vơi tap cat ket tuoi Oligocen ơ ca hai gieng khoan. Va theo phương nam ngang thi tap cat ket ơ gieng khoan " $Y$ " co chat lương kem hơn so vơi gieng khoan " $\mathrm{X}$ ".

\section{Đóng góp của các tác giả}

Nguyen Lâm Anh - Chiu trach nhiem chınh ve y tương khoa hoc va bo cuc va phac thao noi dung bai bao; Hoang Văn Long - Luan giai nguon tram tıch va biên tap bai bao; Nguyen Thanh Tung,
Nguyen Trung Hieu - Minh giai tai lieu đia chan; Bui Viet Dung, Nguyen Tuan Anh, Trinh Thanh Trung Thu thap va luan giai đia tang khu vưc nghiên cưu; Bui Thi Ngoc Phương, Nguyen Tan Trieu - Phân tıch mau đo hat va mau thach hoc.

\section{Tài liệu tham khảo}

Blott, S. J., K. Pye. (2001). Gradistat: A grain size distribution and statistics package for the analysis of unconsolidated sediments. Earth Surf. Process. Landforms, 26, 1237 - 1248.

Dickinson, W. R., C. A. Suczek. (1979). Plate tectonics and sandstone compositions. American Association of Petroleum Geologists Bulletin, 63, 2164 - 2184.

Dickinson, W. R., L. S. Beard, G. R. Brakenrige, J. L. Erjavec, R. C. Ferguson, K. F. Inman, K. R.A., F. A. Lindberg, P. T. Ryberg. (1983). Provenance of North American Phanerozoic sandstone in relation to tectonic setting. Geol, Soc. America Bull, 94, 222 - 235.

Đỗ Bạt, Nguyễn Địch Dỹ, Phan Huy Quynh, Phạm Hong Que, Nguyen Quy Hung, Đo Viet Hieu va Chu Đức Quang. (2019). Địa tầng các bể trầm tích Kainozoi Việt Nam. Địa chất và Tài nguyên dầu khí Việt Nam. Nhà xuat bản Khoa học và Kỹ thuật, 161 - 208.

Folk, R. L. (1954). The distinction between grain size and mineral composition in sedimentary rock nomenclature. Journal of Geology, 62. 334 $-359$.

Folk, R. L., W. C. Ward. (1957). Brazos River bar: a study in the significance of grain size parameters. Journal of Sedimentary Petrology 27.3 - 26.

Hoàng Ngọc Đông, (2012). Đặc điểm địa chất - kiến tạo phần Đông Bắc bồn trũng Củu Long trong thời kỳ Eocen - Oligocen. Luận án Tien sl, Trường Đại học Mỏ - Địa chat.

Lê Văn Cự, Hoàng Ngọc Đang, Trần Văn Trị và Nguyen Quang Tuan. (2019). Cơ chế hình thành và các kiểu bể trầm tích Kainozoi Việt Nam. Địa chất và Tài nguyên dầu khí Việt Nam. Nhà xuat bản Khoa học và Kỹ thuật, 128 - 160.

Nguyen Hoai Chung, Nguyen Thi Tham, Nguyen Thanh Tuyen, Mai Hoang Đam, Nguyen Văn Sư, 
Bui Thi Ngoc Phương, Nguyen Tan Trieu, Pham Thi Toan và Lê Thị Việt Phương, (2019a). Báo cáo phân tích cổ sinh địa tầng giếng khoan $R$ - 55. Thành phố Hồ Chí Minh. VPI Lab. Viện Dầu khí Việt Nam. 63.

Nguyen Hoai Chung, Nguyen Thi Tham, Nguyen Thanh Tuyen, Mai Hoang Đam, Nguyen Văn Sư, Bui Thi Ngoc Phương, Nguyen Tan Trieu, Pham Thi Toan và Lê Thi Viet Phương, (2019b). Báo cáo phân tích cổ sinh địa tầng giếng khoan $R$ - 60. Thành phố Hồ Chí Minh. VPI Lab. Viện Dầu khí Việt Nam. 71.

Schmidt, W. S., H. H. Bui, J. W. Handschya, T. H. Vu, X. C. Trinh, T. T. Nguyen. (2019). Tectonic evolution and regional setting of the Cuu Long Basin, Vietnam. Tectonophysics, 757, 36 - 57.

Tạ Thị Thu Hoai and Phạm Huy Long. (2009). Cac giai đoạn biến dạng ơ bon trung Cưu Long. Tạp chí Phát triển Khoa học \& Công nghệ, 12, 110 116.

Trần Lê Đông, Phùng Đắc Hải và Đỗ Quang Đối (2019). Bể trầm tích Cửu Long và tiềm năng dầu khí. Địa chất và Tài nguyên dầu khí Việt Nam. Nhà xuất bẳ Khoa học và Kỹ thuật, 318 - 389.

Vietnam Petroleum Institute. (2011). Cuu Long Basin in Overview of Petroleum Basins in Vietnam (Internal report). Vietnam Petroleum Institute. 1-66. 